\title{
Evaluating Accessibility of Malaysian Public Universities Websites using Achecker and Wave
}

Article · January 2016

CITATIONS

0

2 authors:

Aidi Ahmi

Universiti Utara Malaysia

14 PUBLICATIONS 32 CITATIONS

SEE PROFILE
READS

13

Rosli Mohamad

Universiti Utara Malaysia

13 PUBLICATIONS 40 CITATIONS

SEE PROFILE 


\title{
EVALUATING ACCESSIBILITY OF MALAYSIAN PUBLIC UNIVERSITIES WEBSITES USING ACHECKER AND WAVE
}

\author{
Aidi Ahmi \& Rosli Mohamad \\ Universiti Utara Malaysia, Malaysia \\ aidi@uum.edu.my; roslim@uum.edu.my
}

\begin{abstract}
Websites become essential means for most universities to communicate, exchange of relevant information and enable transactions among their stakeholders. Therefore, website accessibility accessible website is crucial to students to ensure equal access to of the university's information regardless of their physical disabilities and other possible limitations. This study reports the web accessibility of 20 Malaysian public universities based on AChecker and WAVE. The results suggest a relatively low level of compliance to the guidelines as specified in WCAG 2.0 and Section 508. Among the aspects that deserve immediate attention are the provision of text alternatives for any non-text contents, keyboard accessibility and colour contrast. Other concerns such as navigation, adaptability, input assistance, compatibility, empty link and empty heading can be further improved. Regardless of low conformance, most websites extensively integrated some of the accessibility features as set out by Section 508. Overall, this study offers meaningful insights, particularly to web developers for better compliance with the standards while designing their websites.
\end{abstract}

Keywords: automated accessibility tools, Malaysian public university, Section 508, WCAG 2.0, web accessibility.

\section{INTRODUCTION}

Evolving Internet functionalities since 1990s have enabled dramatic improvement for business communication. Nowadays, websites are gaining popularity as one of the potential means for disseminating or exchanging of 
information with various stakeholders. In fact, a website offer dual side benefits to both the information provider and the information requester (users). For the former, the website enables the business to effectively supply information to the targeted audience. As for the latter, the website features employed, ensure users to have better access to richer information/services apart from having a smooth navigational experience (Williams \& Rattray, 2005).

Unlike the private sector, public institutions employ websites to improve the delivery of services to the citizens or other related stakeholders. Specifically, setting up a highly effective website is crucial for the information-intensive sector such as public universities. The website turns to be a resource centre for the stakeholders, which includes prospective and current students, potential and existing employees, visitors and the alumni. Furthermore, due to a growing trend among students to seek information for pursuing their higher degrees (Schimmel et al., 2010), an effective web-based communication channel helps institutions to address the students' information needs. Nevertheless, having necessary information available is not sufficient unless it is made accessible to the stakeholders (Kamoun \& Almourad, 2014).

Accessibility represents one of the web-quality aspects that ensures effective use of the website, ease of navigation and understanding its structure despite having physical disabilities or other constraints (Shawn, 2006). The World Wide Web Consortium (W3C) (2009) states that an accessible website supports people with disabilities to perceive, understand, navigate, and interact effectively for equal chances to contribute to the web communication activities. Thus, web accessibility guarantees that all potential users can access web applications regardless of an individual's limitations or the context of use. The definitions imply that web accessibility is not only restricted to the needs of people with physical disabilities to use the web but also to include people with different skills, preferences and needs. This includes individuals who have slow Internet connection, suffer from temporary or age-related disabilities and have different technological capabilities such as browser type, screen sizes, or device type (Andrés, Lorca \& Martínez, 2010; Providenti \& Zai III, 2011). In short, web accessibility concerns are beyond the need of disabled people. More importantly, accessibility concerns the ability of users to navigate the website by taking into consideration the differences in their requirements and contextual environment. Apart from augmenting browsing experience, an accessible website also facilitates organisations to have effective website updating activities (Hofstader, 2004), offers better web visibility and increases traffics to its website (Williams \& Rattray, 2005). As such, institutions have to design websites that are highly flexible to address all these diversities and potentials (W3C, 2005). 
While earlier studies focused on different organisational contexts and employed various accessibility software, this study reports the accessibility of the Malaysian public universities websites. Specifically, the objectives of this study are twofold,. Firstly, to report the current status of public universities compliance on web accessibility as stipulated by the most recent guidelines i.e. WCAG 2.0 and Section 508 of the United States Rehabilitation Act 1973, secondly, to identify areas with highest incidences of non-compliance that could be useful sources to rectify the problems (as per reports of AChecker and WAVE automated tools).

Similar to other countries, the web accessibility issue deserves special attention in Malaysia. The Law of Malaysia (2008) on Person with Disabilities Act 2008 (Act 685) (Part IV) clearly specifies the equal rights of the disabled people to access any public facilities or services, which include basic facilities, infrastructure, transportation, education, employment and access to ICT-related services. Specifically, the government and the information providers have to provide ICT services in a format which is accessible to people with different kinds of disabilities without additional cost (Section 30, para 1 to 3). With the number of disabled people increasing to about $69 \%$, from 314,247 in 2010 to 531,962 in 2014 the (Department of Social Welfare, 2014), government has taken their education as one of the priorities in the government agenda. As specified clearly in the Person with Disabilities Act (2008), education for persons with disabilities should form an integral part of national educational planning, curriculum development and school organization. As of 2013, about 1,572 of the 481,361 students enrolled in public higher institutions nationwide are those with certain disabilities (Ministry of Higher Education [MOHE], 2014). Thus, public universities are expected to comply with the Act so as to ensure equal access of information, resources, facilities and ICT (including website) to these group of students.

Investigation of the web accessibility of public universities also resembles the government's initiative to strengthen public sector efficiency via the Malaysian Government Portals and Websites Assessment (MGPWA). A project spearheaded by the Multimedia Development Corporation (MDeC) aims to heighten government service delivery amongst the public sectors. Conformance to W3C Disability Accessibility standard was among the criteria specified in the MGPWA guideline.

The outcome of this study facilitates web development activities amongst public universities. Web accessibility evaluation facilitates reengineer the process of the website after the stage for the purpose of continuous 
improvement of the website performance (Boldyref, 2002). Moreover, continuous efforts to understand users' requirements can be a starting point towards more effective website development strategies (Yates, 2005). In the context of public universities, having more accessible websites warrants equal access to educational related information for disabled people (Shawar, 2015), apart from taking care of diverse stakeholders needs for better web surfing experience.

\section{WEB ACCESSIBILITY GUIDELINE AND STANDARDS}

The World Wide Web Consortium (W3C), an international consortium that combines full-time employees and the public towards cumulative efforts to propose a standard for web accessibility. The Consortium initiated an exercise known as Web Accessibility Initiative (WAI), which later produced the Web Content Accessibility Guidelines (WCAG). The guideline becomes the defacto standard for evaluating accessibility of the web (Rømen \& Svanæs, 2012). The first version of the guideline (WCAG 1.0) that came into picture in the late 1990s, offered guidelines in designing accessible websites regardless of the physical, sensory or cognitive abilities of the audience. While W3C does not impose any legal enforcement of the guideline, it does offer meaningful insight to make more accessible websites (Yates, 2005).

W3C officially released a newer version (WCAG 2.0) in 2008 (W3C, 2008), which encompassed a wider range of recommendations for accessible web content. The guideline was grounded on four principles, perceivable, operable, understandable, and robust (Peters \& Bradbad, 2010). As WCAG (2008) outlined perceivable principle concerned the presentation of information and user interface components that facilitate them to perceive. Meanwhile, operable denotes of the operability of user-interface components and navigation functionalities. The third principle focused on understandable presentation of information and user-interface operation. Finally, the robust principle stressed the reliable interpretation of the web content regardless of the user agents used. The WCAG 2.0 guideline further extended the accessibility conformance into five distinct aspects; conformance level, full page, complete processes, only accessibility-supported ways of using technologies and noninterference (W3C, 2009).

The revised guideline comprised of 12 guidelines and 61 success criteria with three levels of conformance, i.e. Priority 1 (Level A), Priority 2 (Level AA) and Priority 3 (Level AAA) (W3C, 2008). Level A (the lowest compliance) 
specified the compulsory elements of the web for people with disability to get access to the materials provided. Meanwhile, Level AA listed the advanced requirements that likely removed significant accessibility barriers for a wider group of audience to be able to access the web content. The highest conformance level (Level AAA) stipulated other advanced features that ensured widest accessibility of the web among the audience. Meeting the requirements of the least Priority 1 was crucial for most organisations in order to offset between an economic performance and a social/moral performance (Williams \& Rattray, 2005). All in all, the revised requirements made WCAG 2.0 more educational, able to produce reliable results, testable elements, and produce unambiguous interpretation (Ribera, Porras, Boldu, Termens, Sule, \& Paris, 2009).

Similarly, Section 508 of the United States Rehabilitation Act 1973 also addressed the issue of equal access amongst the disabled. The act required the US federal agencies to provide equal access to electronic and information technology applications. The Act stressed on 16 web components in designing and presenting accessible websites (WebAiM, 2013).

\section{AUTOMATED TOOLS FOR WEB ACCESSIBILITY}

Considering the complexity of the web functionalities, the emergence of automated tools complement the existing standards/guidelines to objectively evaluate web accessibility compliance. At present, there are various automated tools to assist quick and objective reviews of web accessibility. Accessibility Valet, AChecker, Cynthia Says, EvalAccess, FAE, MAGENTA, OCAWA, TAW, WAVE and Web Accessibility Checker are the top-10 free tools that are available on the net (Source: http://usabilitygeek.com/10-free-web-basedweb-site-accessibility-evaluation-tools). The tools that are capable of quickly generating assessment results, are easy to use and offer great usability explain their popularity (Lujan-Mora, Navarrete, \& Penafiel, 2014). In addition, automated tools that highly correspond to the applicable web accessibility standards/guidelines further enhance reliability and relevancy of the results generated. Table 1 shows the selected tools and their embedded web accessibility standards. While automated tools are highly useful to objectively predict web accessibility, part of the results reported require human judgment or manual inspection of the web (Peters \& Bradbad, 2010). Hence, interpretation of the results generated from an automated tool deservescareful scrutiny and should be interpreted within its limitations. 
Table 1

Most Popular Automated Accessibility Tools and Applicable Standards

\begin{tabular}{lccc}
\hline & \multicolumn{3}{c}{ Accessibility guidelines adapted } \\
\hline Tool & WCAG1.0 & WCAG2.0 & Section 508 \\
Accessibility Valet & Yes & No & Yes \\
AChecker & Yes & Yes & Yes \\
Cynthia Says & Yes & No & Yes \\
EvalAccess & Yes & No & No \\
FAE & No & No & No \\
MAGENTA & Yes & No & No \\
OCAWA & Yes & No & No \\
TAW & Yes & Yes & No \\
WAVE & Yes & Yes & Yes \\
Web Acc Checker & Yes & Yes & Yes \\
\hline Adapt
\end{tabular}

Adapted from http://usabilitygeek.com/10-free-web-based-web-site-accessibilityevaluation-tools

\section{EARLIER WORKS ON WEB ACCESSIBILITY}

Responding to the importance of web accessibility, a considerable number of studies have been reported in various types of organisations such as libraries (Comeaux \& Schmetzke, 2013; Providenti \& Zai III, 2011), hotels (Williams \& Rattray, 2005), accounting firms (William \& Rattray, 2003) and public sectors (Baowaly \& Bhuiyan, 2012; Kamoun \& Almourad, 2014; Pribeanu, Marinescu, Fogarassy-Neszly, \& Moisii, 2012; Bakhsh \& Mehmood, 2012; Lujan-Mora, Navarrete \& Penafiel, 2014; Noh, Jeong, You, Moon, \& Kang, 2015; Shi, 2006; Serra, Carvalho, Ferreira, Vaz, and Friere, 2015).

Several studies have evaluated web accessibility of higher learning institutions. Using HERA and WAVE as the assessment tools, Adepoju and Shehu (2014) reported substantial incompliance of 36 Nigerian federal universities' websites on accessibility guidelines. Similarly, an examination of 74 Spanish universities reported low to moderate levels of compliance on accessibility standard (Chacón-Medina, Chacón-López, López-Justicia, \& FernándezJiménez, 2013). Laitano (2015) who diagnosed Argentine public universities, websites based on WCAG 2.0 guidelines indicated serious accessibility issues for most parts of the websites, particularly on the syntax, presentation of the web content and non-text content, and visual readability of the text. Finally, a 
cross-countries study on selected higher education institutions in the Middle East and England concluded that website accessibility in developed countries was better off than the developing economies (Shawar, 2015).

Despite the claim that e-government practice is improving in Malaysia and the websites are showing higher maturity (Abdul Rashid, Othman, \& Hassan, (2014), studies on web accessibility indicate otherwise. Abdul Aziz, Wan Mohd Isa and Nordin's (2010) investigation on 120 websites of higher education institutions pointed out various accessibility and usability issues. Lastly, a longitudinal study on Malaysian public higher institutions' websites using three automated tools showed little improvement of web accessibility over a two-year period (Abuaddous, Jali \& Basir, 2013). Other than the studies on higher institutions, several studies on other sectors are worth mentioning. Abdul Latif and Masrek (2010) reported the current status of Malaysian e-government websites and attained webmasters' perception on web accessibility. As the study reported, all the websites did not even meet the lowest accessibility compliance level (Priority 1). Viewing the issue from the disabled group perspective, another study found that the use of images, hyperlinks and page layouts on the website failed to meet the requirements of visually impaired persons (Ramayah, Jaafar \& Mohd Yatim, 2010).

With respect to the assessment tools, previous works have employed different tools and approaches for evaluating web accessibility. Table 2 offers an insight of the selected tools used in earlier studies. The data indicates popularity and diversity of tools used as objective measure of web accessibility.

Table 2

Application of Automated Tools in Web Accessibility Research

\begin{tabular}{ll}
\hline Automated tool (s) used & Relevant works \\
\hline WAVE & Adepoju \& Shehu (2014); Lujan-Mora, Navarrete \& \\
& Penafiel (2014) \\
AChecker & Adepoju \& Shehu (2014); Lujan-Mora, Navarrete \& \\
& Penafiel (2014); Abuaddous, Jali \& Basir (2013) \\
Total validator & Bakhsh \& Mehmood (2012; Lujan-Mora, Navarrete \& \\
& Penafiel (2014) \\
Bobby & Comeaux \& Schmetzke, 2013; O’Grady \& Harrison \\
& (2003); Loiacono, McCoy \& Chin (2005); Williams \& \\
& Rattray (2005); Shi (2006); Abdul Latif \& Masrek (2010) \\
\hline
\end{tabular}

(continued) 


\begin{tabular}{ll}
\hline Automated tool (s) used & Relevant works \\
\hline TAW & Lujan-Mora, Navarrete \& Penafiel (2014); Abuaddous, Jali \\
& \& Basir (2013) \\
WEBACT & Shi (2006) \\
EvalAccess 2.0 & Abdul Aziz, Wan Mohd Isa \& Nordin (2010) \\
KWCAG 1.0 & Noh, Jeong, You, Moon \& Kang (2015) \\
HERA & Adepoju \& Shehu (2014) \\
\hline
\end{tabular}

Extending from previous works, this study evaluates the current state of web accessibility compliance of Malaysian public universities as outlined by WCAG 2.0 and Section 508. The next section elaborates in greater detail the data collection process and is followed by the findings and discussion of the results.

\section{METHODOLOGY}

This study examined the web accessibility of 20 Malaysian public universities' websites. Considering its popularity, it being freely available and its extensive integration of accessibility standards (WCAG 2.0 and Section 508), this study employed the Accessibility Checker (AChecker) and Web Accessibility Versatile Evaluator (WAVE) as preferred automated tools. As per the WCAG 2.0 standard, websites need to comply with Level A requirements that allow disabled persons to use the websites. This corresponds to the Provider-Based Evaluation (ProBE) 2015 assessment guidelines. ProBE is an initiative by the Multimedia Development Corporation (MDeC) for websites' selfassessment manuals and web maintenance tools for Malaysian government agencies (including the public universities). Although the guidelines specify web accessibility as non-mandatory criteria, their requirement is getting more important over time as one of the strategies to increase web usage and improve user experience.

The authors carried out website accessibility assessment using both automated tools from Monday, 21 March 2016 to Tuesday, 22 March 2016. The assessment particularly focused on the respective institution's homepage. Assessing multiple webpages offers richer information, but this study restricted the assessment to the homepage for a quick review of web accessibility, in view of the dynamic nature of the web. Moreover, as the homepage denotes the entrance to any website, it could be the most up-to-date section of the website 
and the most frequently maintained by the webmaster (Providenti \& Zai III, 2011). The Next section offers a comparison of the web accessibility evaluation result across all institutions based on the automated tools employed.

\section{ANALYSIS AND DISCUSSION}

\section{Web Accessibility Results Based on AChecker}

AChecker evaluated the web accessibility based on two primary guidelines, namely WCAG 2.0 and Section 508. As Table 3 indicates, none of the websites examined passed the lowest accessibility test as set out in WCAG 2 . 0 (Level A), except three institutions (IIUM, UMS and UTEM) that reported conditional passes. In addition, only the IIUM website reported a conditional pass for WCAG 2.0 Level AA and Level AAA requirements respectively. The assessment based on Section 508 guidelines showed that none of the websites passed the test. The high number of errors reported for each level of test is partly because AChecker functions on the most recent standard i.e. WCAG 2.0 and Section 508 that are highly extensive (Adepoju \& Shehu, 2014). Overall, the results provide evidence that the level of compliance with respect to web accessibility requirements is relatively very low amongst the public universities in Malaysia. The results seem consistent with what has been reported by similar studies worldwide such as in the Middle East countries (Shawar, 2015), Nigeria (Adepoju \& shehu, 2014), Argentina (Laitano, 2015) and Malaysia (Abdul Latif \& Masrek, 2010; Abdul Aziz et al., 2010; Abuaddous et al., 2013).

Table 3

AChecker Results Summary Based on WCAG 2.0 and Section 508 by University

\begin{tabular}{|c|c|c|c|c|c|c|c|c|c|c|c|c|c|c|c|c|}
\hline \multirow[t]{2}{*}{ Universities } & \multicolumn{4}{|c|}{$\begin{array}{c}\text { WCAG 2.0 } \\
\text { (Level A) }\end{array}$} & \multicolumn{4}{|c|}{$\begin{array}{l}\text { WCAG } 2.0 \\
\text { (Level AA) }\end{array}$} & \multicolumn{4}{|c|}{$\begin{array}{c}\text { WCAG } 2.0 \\
\text { (Level AAA) }\end{array}$} & \multicolumn{4}{|c|}{ Section 508} \\
\hline & $\mathbf{R}$ & $\mathbf{K}$ & $\mathbf{L}$ & $\mathbf{P}$ & $\mathbf{R}$ & $\mathbf{K}$ & $\mathbf{L}$ & $\mathbf{P}$ & $\mathbf{R}$ & $\mathbf{K}$ & $\mathbf{L}$ & $\mathbf{P}$ & $\mathbf{R}$ & $\mathbf{K}$ & $\mathbf{L}$ & $\mathbf{P}$ \\
\hline IIUM & $\mathrm{C}$ & 0 & 4 & 666 & $\mathrm{C}$ & 0 & 4 & 762 & $\mathrm{C}$ & 0 & 0 & 767 & $\mathrm{~F}$ & 5 & 18 & 82 \\
\hline UiTM & $\mathrm{F}$ & 34 & 1 & 558 & $\mathrm{~F}$ & 34 & 1 & 574 & $\mathrm{~F}$ & 34 & 1 & 579 & $\mathrm{~F}$ & 10 & 33 & 139 \\
\hline UKM & F & 33 & 0 & 784 & F & 131 & 1 & 825 & F & 96 & 1 & 830 & $\mathrm{~F}$ & 61 & 52 & 177 \\
\hline UM & $\mathrm{F}$ & 22 & 0 & 684 & $\mathrm{~F}$ & 39 & 0 & 693 & F & 39 & 0 & 698 & $\mathrm{~F}$ & 53 & 49 & 142 \\
\hline UMK & $\mathrm{F}$ & 30 & 0 & 1199 & $\mathrm{~F}$ & 153 & 0 & 1248 & F & 128 & 0 & 1253 & $\mathrm{~F}$ & 10 & 36 & 232 \\
\hline UMP & $\mathrm{F}$ & 4 & 1 & 486 & $\mathrm{~F}$ & 4 & 3 & 499 & F & 4 & 3 & 504 & $\mathrm{~F}$ & 4 & 18 & 80 \\
\hline UMS & $\mathrm{C}$ & 0 & 4 & 731 & $\mathrm{~F}$ & 11 & 4 & 752 & $\mathrm{~F}$ & 11 & 0 & 757 & $\mathrm{~F}$ & 6 & 27 & 171 \\
\hline
\end{tabular}




\begin{tabular}{|c|c|c|c|c|c|c|c|c|c|c|c|c|c|c|c|c|}
\hline \multirow{2}{*}{ Universities } & \multicolumn{4}{|c|}{$\begin{array}{l}\text { WCAG 2.0 } \\
\text { (Level A) }\end{array}$} & \multicolumn{4}{|c|}{$\begin{array}{l}\text { WCAG 2.0 } \\
\text { (Level AA) }\end{array}$} & \multicolumn{4}{|c|}{$\begin{array}{c}\text { WCAG 2.0 } \\
\text { (Level AAA) }\end{array}$} & \multicolumn{4}{|c|}{ Section 508} \\
\hline & $\mathbf{R}$ & $\mathbf{K}$ & $\mathbf{L}$ & $\mathbf{P}$ & $\mathbf{R}$ & $\mathbf{K}$ & $\mathbf{L}$ & $\mathbf{P}$ & $\mathbf{R}$ & $\mathbf{K}$ & $\mathbf{L}$ & $\mathbf{P}$ & $\mathbf{R}$ & $\mathbf{K}$ & $\mathbf{L}$ & $\mathbf{P}$ \\
\hline UMT & $\mathrm{F}$ & 10 & 0 & 417 & $\mathrm{~F}$ & 100 & 0 & 432 & $\mathrm{~F}$ & 39 & 0 & 439 & $\mathrm{~F}$ & 27 & 25 & 72 \\
\hline UNIMAP & $\mathrm{F}$ & 27 & 2 & 1168 & F & 29 & 2 & 1223 & $\mathrm{~F}$ & 29 & 2 & 1228 & $\mathrm{~F}$ & 21 & 41 & 199 \\
\hline UNIMAS & $\mathrm{F}$ & 14 & 0 & 599 & F & 53 & 0 & 634 & $\mathrm{~F}$ & 53 & 0 & 639 & $\mathrm{~F}$ & 31 & 52 & 199 \\
\hline UNISZA & $\mathrm{F}$ & 4 & 1 & 1418 & F & 5 & 1 & 1472 & $\mathrm{~F}$ & 5 & 1 & 1477 & $\mathrm{~F}$ & 8 & 22 & 340 \\
\hline UPM & $\mathrm{F}$ & 18 & 5 & 1335 & $\mathrm{~F}$ & 36 & 5 & 1404 & $\mathrm{~F}$ & 33 & 5 & 1411 & $\mathrm{~F}$ & 28 & 31 & 294 \\
\hline UPNM & $\mathrm{F}$ & 71 & 0 & 983 & $\mathrm{~F}$ & 101 & 0 & 1016 & $\mathrm{~F}$ & 73 & 0 & 1021 & $\mathrm{~F}$ & 9 & 22 & 202 \\
\hline UPSI & $\mathrm{F}$ & 1 & 0 & 1170 & $\mathrm{~F}$ & 69 & 0 & 955 & $\mathrm{~F}$ & 70 & 0 & 960 & $\mathrm{~F}$ & 43 & 51 & 186 \\
\hline USIM & $\mathrm{F}$ & 3 & 0 & 1030 & $\mathrm{~F}$ & 14 & 0 & 1055 & $\mathrm{~F}$ & 14 & 0 & 1060 & $\mathrm{~F}$ & 4 & 30 & 175 \\
\hline USM & $\mathrm{F}$ & 6 & 1 & 480 & $\mathrm{~F}$ & 6 & 1 & 505 & $\mathrm{~F}$ & 6 & 1 & 510 & $\mathrm{~F}$ & 5 & 13 & 80 \\
\hline UTEM & $\mathrm{C}$ & 0 & 2 & 539 & F & 18 & 2 & 563 & $\mathrm{~F}$ & 18 & 2 & 568 & $\mathrm{~F}$ & 6 & 26 & 130 \\
\hline UTHM & $\mathrm{F}$ & 1 & 0 & 1170 & $\mathrm{~F}$ & 1 & 0 & 1203 & $\mathrm{~F}$ & 1 & 0 & 1208 & $\mathrm{~F}$ & 11 & 17 & 234 \\
\hline UTM & $\mathrm{F}$ & 74 & 0 & 1066 & $\mathrm{~F}$ & 238 & 0 & 1104 & $\mathrm{~F}$ & 89 & 0 & 1112 & $\mathrm{~F}$ & 45 & 48 & 231 \\
\hline UUM & F & 25 & 1 & 859 & $\mathrm{~F}$ & 26 & 1 & 877 & $\mathrm{~F}$ & 26 & 1 & 880 & $\mathrm{~F}$ & 4 & 21 & 174 \\
\hline TOTAL & & 377 & 22 & 17342 & & 1068 & 25 & 17796 & & 768 & 17 & 17901 & & 391 & 632 & 3539 \\
\hline
\end{tabular}

Legend: $\mathrm{R}=$ Result, $\mathrm{K}=$ Known problems, $\mathrm{L}=$ Likely problems, $\mathrm{P}=$ Potential problems, $\mathrm{F}=$ Fail, $\mathrm{P}=$ Pass, $\mathrm{C}=$ Conditional pass

AChecker classifies accessibility-related problems into three categories. (a) known problems, i.e. the problems that have been identified with certainty as accessibility barriers, (b) likely problems, i.e. the problems that have been identified as probable barriers, but requires further subjective assessment and (c) potential problems which refer to the problems that A Checker is unable to detect, which demands for manual inspection of the web. For known problem, AChecker inspects 12 primary issues with several criteria being specified to evaluate each of the issues concerned. The Known Problems identified are crucial, thus, requiring immediate attention of the web developer. Table 4 reports the known problems as generated by AChecker for all levels of WCAG 2.0 specification.

As per Level A requirements, one of the issues that deserves further attention is keyboard accessibility with 149 incidences of errors (40 percent) for all websites. Among the concerns over keyboard accessibility is on pairing of attributes. In case the website contains an onmousedown attribute, it must also contain an onkeydown attribute, and if it contains an onmouseout attribute, it must also contain an onblur attribute. Meanwhile, if the website contains an onmouseover attribute, it must also contain an onfocus attribute; and if it contains an onmouseup attribute, it must also contain an onkeyup attribute. 
Table 4

Known Problems as per WCAG 2.0

\begin{tabular}{|c|c|c|c|c|c|c|c|}
\hline \multicolumn{2}{|c|}{ Known Problems* } & \multicolumn{2}{|c|}{$\begin{array}{l}\text { WCAG2.0 } \\
\text { (Level A) }\end{array}$} & \multicolumn{2}{|c|}{$\begin{array}{r}\text { WCAG2.0 } \\
\text { (Level AA) }\end{array}$} & \multicolumn{2}{|c|}{$\begin{array}{c}\text { WCAG2.0 } \\
\text { (Level } \\
\text { AAA) } \\
\end{array}$} \\
\hline & & Total & $\%$ & Total & $\%$ & Total & $\%$ \\
\hline 1.1 & $\begin{array}{l}\text { Text alternatives: Provide text alternatives for } \\
\text { any non-text content. }\end{array}$ & 97 & 26 & 369 & 35 & 137 & 18 \\
\hline 1.2 & $\begin{array}{l}\text { Time-based media: Provide alternatives for } \\
\text { time-based media. }\end{array}$ & $\mathrm{n} / \mathrm{a}$ & $\mathrm{n} / \mathrm{a}$ & $\mathrm{n} / \mathrm{a}$ & $\mathrm{n} / \mathrm{a}$ & $\mathrm{n} / \mathrm{a}$ & $\mathrm{n} / \mathrm{a}$ \\
\hline 1.3 & $\begin{array}{l}\text { Adaptable: Create content that can be } \\
\text { presented in different ways (for example } \\
\text { simpler layout) without losing information or } \\
\text { structure. }\end{array}$ & 35 & 9 & 41 & 4 & 35 & 5 \\
\hline 1.4 & $\begin{array}{l}\text { Distinguishable: Make it easier for users to } \\
\text { see and hear content including separating } \\
\text { foreground from background. }\end{array}$ & 0 & 0 & 333 & 31 & 334 & 43 \\
\hline 2.1 & $\begin{array}{l}\text { Keyboard accessible: Make all functionalities } \\
\text { available from a keyboard. }\end{array}$ & 150 & 40 & 152 & 14 & 152 & 20 \\
\hline 2.2 & $\begin{array}{l}\text { Enough time: Provide users enough time to } \\
\text { read and use content. }\end{array}$ & 0 & 0 & 0 & 0 & 0 & 0 \\
\hline 2.3 & $\begin{array}{l}\text { Seizures: Do not design content in a way that } \\
\text { is known to cause seizures. }\end{array}$ & $\mathrm{n} / \mathrm{a}$ & $\mathrm{n} / \mathrm{a}$ & $\mathrm{n} / \mathrm{a}$ & $\mathrm{n} / \mathrm{a}$ & $\mathrm{n} / \mathrm{a}$ & $\mathrm{n} / \mathrm{a}$ \\
\hline 2.4 & $\begin{array}{l}\text { Navigable: Provide ways to help users } \\
\text { navigate, find content, and determine where } \\
\text { they are. }\end{array}$ & 66 & 18 & 140 & 13 & 82 & 11 \\
\hline 3.1 & $\begin{array}{l}\text { Readable: Make text content readable and } \\
\text { understandable. }\end{array}$ & 3 & 1 & 3 & 0 & 3 & 0 \\
\hline 3.2 & $\begin{array}{l}\text { Predictable: Make web pages appear and } \\
\text { operate in predictable ways. }\end{array}$ & $\mathrm{n} / \mathrm{a}$ & $\mathrm{n} / \mathrm{a}$ & $\mathrm{n} / \mathrm{a}$ & $\mathrm{n} / \mathrm{a}$ & $\mathrm{n} / \mathrm{a}$ & $\mathrm{n} / \mathrm{a}$ \\
\hline 3.3 & $\begin{array}{l}\text { Input Assistance: Help users avoid and correct } \\
\text { mistakes. }\end{array}$ & 18 & 5 & 23 & 2 & 18 & 2 \\
\hline 4.1 & $\begin{array}{l}\text { Compatible: Maximize compatibility with } \\
\text { current and future user agents, including } \\
\text { assistive technologies. }\end{array}$ & 8 & 2 & 7 & 1 & 7 & 1 \\
\hline \multicolumn{2}{|c|}{ TOTAL } & 377 & 100 & 1068 & 100 & 768 & 100 \\
\hline
\end{tabular}

Consistent with Bakhsh and Mehmood (2012), errors reported from Level AA are the highest among the three assessment components. Level AA recommends the provision of text alternatives for any non-text content such as image, area, embed and input elements. Higher incidences of such error 
(35\%) are in parallel with previous studies (Abdul Latif \& Masrek 2010; Adepoju \& Shehu, 2014; Hackett \& Parmanto, 2005; Pribeanu et al., 2012). The presence of text alternative enables the content to be presented to the users as per its original content (Abdul Latif \& Masrek, 2010). Its presence is more paramount if the non-text element complements a webpage content or it is associated to a function of the page (Providenti \& Zai, 2007). Thus, this error calls for special attention by the web developer.

As for the Level AAA category, the criteria that requires serious attention are the selection of colour (distinguishable), particularly the selection of colour between the text and the background, link text and background, active link text and background or visited link text and background. The optimal contrast ratio must be at least 7:1 for easily distinguishable content. Meeting the specified contrast ratio facilitates users to easily recognise the text and to separate the foreground from the background of the web page. Application of lower colour contrast causes difficulty for certain users to view or to read the web content (Roggio, 2016). The issue of contrast colours is also reported as the second highest occurrence as per Level AA category (333 incidences or 33\%). Level AA requires a minimum contrast ratio level of 5:1.

Other problems that deserve further attention include navigability, adaptability, input assistance and compatibility. A navigable website provide ways to assist users to navigate, to find content, and to determine where they are while browsing in the website. Adaptability is essential through which the web administrator ensures separation of information and structure from the presentation. Provision of input assistance helps users to avoid and correct mistakes, while compatibility ensures the website supports current and future user agents, including assistive technologies. The issues marked as not applicable (n/a) represent the issues not being classified as known problems. Instead, AChecker classifies these issues as likely problems or potential problems.

By referring to Section 508 requirements, AChecker reports three issues out of 16 standards listed in Table 5. Similar to Bakhsh and Mehmood's (2012) finding, the first issue that requires further attention is the use of script with 240 occurrences of errors (61\% of total errors) reported for non-compliance of this standard. The standard requires every script elements that occurs within the body must be followed by a noscript section. 
Table 5

Problems as per Section 508

\begin{tabular}{lcccccc}
\hline \multirow{2}{*}{ Section 508 } & \multicolumn{2}{c}{$\begin{array}{c}\text { Known } \\
\text { problems }\end{array}$} & \multicolumn{2}{c}{$\begin{array}{c}\text { Likely } \\
\text { problems }\end{array}$} & \multicolumn{2}{c}{$\begin{array}{c}\text { Potential } \\
\text { problem }\end{array}$} \\
\cline { 2 - 7 } & Total & $\mathbf{\%}$ & Total & $\mathbf{\%}$ & Total & $\mathbf{\%}$ \\
\hline A - Text equivalents & 131 & 34 & 61 & 10 & 1047 & 30 \\
B - Multimedia equivalents & 0 & 0 & 0 & 0 & 0 & 0 \\
synchronized & & & & & & \\
C - Color also available without color & 0 & 0 & 0 & 0 & 1730 & 49 \\
D - Stylesheets in use & 0 & 0 & 571 & 90 & 0 & 0 \\
E - Text links for server-side image map & 0 & 0 & 0 & 0 & 0 & 0 \\
F - Client-side image maps instead of & 0 & 0 & 0 & 0 & 0 & 0 \\
server-side & & & & & & \\
G - Row/column headers for data tables & 0 & 0 & 0 & 0 & 166 & 5 \\
H - Associate data cells and header cells & 0 & 0 & 0 & 0 & 0 & 0 \\
I - Frames shall be titled & 0 & 0 & 0 & 0 & 0 & 0 \\
J - Avoid flicker & 0 & 0 & 0 & 0 & 574 & 16 \\
K - Text-only page & 0 & 0 & 0 & 0 & 0 & 0 \\
L - Script must have functional text & 240 & 61 & 0 & 0 & 0 & 0 \\
M - Applets etc. must comply & 0 & 0 & 0 & 0 & 0 & 0 \\
N - Accessible forms & 20 & 5 & 0 & 0 & 2 & 0 \\
O - Skip repetitive navigation links & 0 & 0 & 0 & 0 & 20 & 1 \\
P - Timed response & 0 & 0 & 0 & 0 & 0 & 0 \\
\hline Total & $\mathbf{3 9 1}$ & $\mathbf{1 0 0}$ & $\mathbf{6 3 2}$ & $\mathbf{1 0 0}$ & $\mathbf{3 5 3 9}$ & $\mathbf{1 0 0}$ \\
\hline
\end{tabular}

The second issue is about the text equivalent (or text alternative as per previous findings under WCAG 2.0 Level AA,) in which all images must have an alternate text (34\% of total reported errors). People who are unable to visually view the image depend highly on this feature. Additionally,the image element should not have an alternate attribute value of null or whitespace if the image element is contained by an A element and there is no other link text. If the image is used as a link, then it must provide an alternate text that describes the link destination.

Similar to the findings of related studies (Adepoju \& Shehu, 2014; Providenti \& Zai, 2007), the third issue that requires the web administrator's attention is accessible form. Select element or input element that contains a type attribute value of text, image, password, checkbox, file or radio must have an associated label element. Thus, web administrators must add a label element that surrounds the control's label. They must set the for attribute on the label 
element to the same value as the id attribute of the control and/or add a title attribute to the input element and/or create a label element that contains the input element.

\section{Web Accessibility Results Based on WAVE}

Table 6 shows the summary of the web accessibility results generated by WAVE, a tool embedded in the Google Chrome browser. This tool provides visual feedback about the accessibility of the web content by injecting icons and indicators onto the page. All analysis were entirely carried out within the browser. WAVE analyses the web accessibility errors, alerts, features, structural elements, HTML5 and Accessible Rich Internet Applications (ARIA) and contrast errors based on WCAG 2.0 (Level A), WCAG 2.0 (Level AA) and Section 508.

Table 6

WAVE Result Summary of the Malaysian Public University Websites*

\begin{tabular}{lcccccc}
\hline Errors & Alerts & Features & $\begin{array}{c}\text { Structural } \\
\text { elements }\end{array}$ & $\begin{array}{c}\text { HTML5 and } \\
\text { ARIA }\end{array}$ & $\begin{array}{c}\text { Contrast } \\
\text { errors }\end{array}$ \\
\hline IIUM & 0 & 32 & 20 & 120 & 15 & 23 \\
UiTM & 6 & 34 & 38 & 29 & 56 & 36 \\
UKM & 87 & 45 & 43 & 55 & 26 & 80 \\
UM & 24 & 129 & 15 & 50 & 12 & 26 \\
UMK & 33 & 87 & 57 & 112 & 3 & 13 \\
UMP & 11 & 41 & 41 & 54 & 3 & 54 \\
UMS & 1 & 69 & 54 & 24 & 3 & 25 \\
UMT & 14 & 10 & 4 & 26 & 7 & 12 \\
UNIMAP & 2 & 111 & 64 & 146 & 6 & 104 \\
UNIMAS & 28 & 33 & 10 & 43 & 4 & 79 \\
UNISZA & 6 & 92 & 138 & 89 & 9 & 5 \\
UPM & 3 & 76 & 85 & 109 & 0 & 61 \\
UPNM & 0 & 112 & 153 & 120 & 225 & 33 \\
UPSI & 23 & 43 & 62 & 40 & 1 & 79 \\
USIM & 5 & 56 & 53 & 81 & 8 & 28 \\
USM & 7 & 27 & 44 & 54 & 5 & 5 \\
UTEM & 0 & 24 & 35 & 26 & 4 & 32 \\
UTHM & 5 & 323 & 86 & 56 & 0 & 3 \\
UTM & 25 & 220 & 53 & 63 & 48 & 15 \\
UUM & 2 & 28 & 65 & 58 & 10 & 38 \\
\hline TOTAL & $\mathbf{2 8 2}$ & $\mathbf{1 5 9 2}$ & $\mathbf{1 1 2 0}$ & $\mathbf{1 3 5 5}$ & $\mathbf{4 4 5}$ & $\mathbf{7 5 1}$ \\
\hline
\end{tabular}

* Findings as at $21^{\text {st }}$ March 2016 


\section{Web Accessibility Errors}

The overall results revealed that almost all the websites reported at least one error except IIUM, UPNM and UTeM that passed the web accessibility test. Nine of the websites reported between one and 10 errors, two of the websites reported between 11 and 20 errors while the remaining two websites contained 33 and 87 errors respectively. Table 7 reveals the summary of errors for all the websites.

Table 7

Web Accessibility Errors as Reported by WAVE

\begin{tabular}{lcc}
\hline Errors & Number of webs & Percentage \\
\hline 0 error & 3 & 15 \\
$1-10$ errors & 9 & 45 \\
$11-20$ errors & 2 & 10 \\
$21-30$ errors & 4 & 20 \\
$31-40$ errors & 1 & 5 \\
More than 41 errors & 1 & 5 \\
\hline Total & $\mathbf{2 0}$ & $\mathbf{1 0 0}$ \\
\hline
\end{tabular}

Table 8 reports the details of the errors detected by WAVE that requires the web administrator's immediate attention. The most commonly found error amongst the websites was an empty link, i.e. the link provided in the website contains no text. This corresponds to several other studies (Adepoju \& Shehu, 2014; Shawar, 2015). To rectify this error, the webmaster should provide the text within the link that describes the functionality and/or target of the link. The second highest incidence of errors is related to missing alternative text for images. Basically, an alternative text provides a textual alternative to non-text content in the website and it becomes a barrier to accessibility especially for screen-reader users (Smith, 2007). The third error with the highest occurrences refers to the empty heading, in which the heading contains no content. The web administrator must ensure that all headings contain informative content. According to WAVE, some users, especially keyboard and screen-reader users, often navigate the web based on the heading elements. Hence, an empty heading will produce no information and may cause confusion to the users. Table 8 presents the remaining errors reported by WAVE together with the explanation of its purpose and importance. 
Table 8

WAVE Errors Details

\begin{tabular}{lllcc}
\hline Error & What it means & \multicolumn{1}{c}{ Why it matters } & Frequency & Percentage \\
\hline Empty link & $\begin{array}{l}\text { A link contains no } \\
\text { text. }\end{array}$ & $\begin{array}{l}\text { If a link contains no text, the } \\
\text { function or purpose of the } \\
\text { link will not be presented to } \\
\text { the user. This can introduce } \\
\text { confusion to keyboard and } \\
\text { screen reader users. }\end{array}$ & \\
& & & \\
& & & \\
& &
\end{tabular}

\begin{tabular}{lll}
\hline $\begin{array}{l}\text { Missing } \\
\text { alternative }\end{array}$ & $\begin{array}{l}\text { Image alternative } \\
\text { text is not present. }\end{array}$ & $\begin{array}{l}\text { Each image must have an alt } \\
\text { attribute. Without alternative } \\
\text { text }\end{array}$ \\
& & will not be available to \\
& screen-reader users or when \\
& the image is unavailable.
\end{tabular}

\begin{tabular}{|c|c|c|c|c|}
\hline $\begin{array}{l}\text { Empty } \\
\text { heading }\end{array}$ & $\begin{array}{l}\text { A heading contains } \\
\text { no content. }\end{array}$ & $\begin{array}{l}\text { Some users, especially } \\
\text { keyboard and screen-reader } \\
\text { users, often navigate by } \\
\text { heading elements. An } \\
\text { empty heading will present } \\
\text { no information and may } \\
\text { introduce confusion. }\end{array}$ & 33 & 11.83 \\
\hline
\end{tabular}

\begin{tabular}{|c|c|c|c|c|}
\hline $\begin{array}{l}\text { Linked image } \\
\text { missing } \\
\text { alternative } \\
\text { text }\end{array}$ & $\begin{array}{l}\text { An image without } \\
\text { alternative text } \\
\text { results in an empty } \\
\text { link. }\end{array}$ & $\begin{array}{l}\text { Images that are the only } \\
\text { thing within a link must have } \\
\text { descriptive alternative texts. } \\
\text { If an image is within a link } \\
\text { that contains no text and that } \\
\text { image does not provide an } \\
\text { alternative text, a screen- } \\
\text { reader has no content to } \\
\text { present to the user regarding } \\
\text { the function of the link. }\end{array}$ & 19 & 6.81 \\
\hline $\begin{array}{l}\text { Missing form } \\
\text { label }\end{array}$ & $\begin{array}{l}\text { A form control } \\
\text { does not have a } \\
\text { corresponding } \\
\text { label. }\end{array}$ & $\begin{array}{l}\text { If a form control does not } \\
\text { have a properly associated } \\
\text { text label, the function or } \\
\text { purpose of that form control } \\
\text { may not be presented to } \\
\text { screen-reader users. Form } \\
\text { labels also provide visible } \\
\text { descriptions and larger } \\
\text { clickable targets for form } \\
\text { controls. }\end{array}$ & 17 & 6.09 \\
\hline
\end{tabular}




\begin{tabular}{|c|c|c|c|c|}
\hline Error & What it means & Why it matters & Frequency & Percentage \\
\hline Empty button & $\begin{array}{l}\text { A button is empty } \\
\text { or has no value } \\
\text { text. }\end{array}$ & $\begin{array}{l}\text { When navigating to a button, } \\
\text { descriptive text must be } \\
\text { presented to screen-reader } \\
\text { users to indicate the function } \\
\text { of the button. }\end{array}$ & 7 & 1.79 \\
\hline $\begin{array}{l}\text { Image button } \\
\text { missing on } \\
\text { alternative } \\
\text { text }\end{array}$ & $\begin{array}{l}\text { Alternative text is } \\
\text { not present for a } \\
\text { form image button. }\end{array}$ & $\begin{array}{l}\text { Image buttons provide } \\
\text { important function that must } \\
\text { be presented an in alternative } \\
\text { text. Without an alternative } \\
\text { text, the function of an image } \\
\text { button is not made available } \\
\text { to screen-reader users or } \\
\text { when images are disabled or } \\
\text { unavailable. }\end{array}$ & 2 & 0.36 \\
\hline Total & & & 282 & 100.00 \\
\hline
\end{tabular}

\section{CONCLUSION, LIMITATIONS AND FUTURE RESEARCH}

In line with the increased reliance on the website to disseminate and communicate relevant information to various stakeholders, public universities in Malaysia should ensure their websites are accessible to all users regardless of their abilities and specific requirements. In response, this paper examined and reports the current status of web accessibility amongst 20 Malaysian public universities. This study employed two automated tools available online, i.e. AChecker and WAVE. Overall, this study indicated a relatively low level of conformance to the web accessibility standards/guidelines. Most of the websites examined did not even pass the minimum web accessibility requirement as stipulated in WCAG 2.0 (Level A). Certain aspects of the website design demand the immediate attention of webmasters to further enhance the accessibility of the website, namely provision of text alternatives for any non-text content, keyboard accessibility and colour contrast. Other issues such as such as navigation, adaptability, input assistance, compatibility, empty link, and empty heading also deserve further attention to enhance web accessibility. Nevertheless, some of the accessibility features and structural elements were being extensively applied by most of the websites. This study provides meaningful insights particularly to the web developers for continuous improvement of their respective university websites for better compliance with the established web accessibility standards. Continuous enhancement of the web accessibility features a better position of the institution based on website ranking tools such as webometric. 
Despite the insightful findings reported, interpretation of the results requires careful consideration on the limitations of the study. First, the results of the present study may not be representative of other categories of universities or organisations. Different categories of institutions or organisation may have been established with different objectives and strategic directions. Nevertheless, the areas of concern are relatively relevant to all web developers or any organisation as part of their improvement initiatives. Secondly, this study employed WAVE and AChecker as the preferred tools to produce an objective evaluation of web accessibility. Obviously, there may be slight variations across the different tools considering the scope and guidelines adopted by each automated tool. This study also did not consider the aspects of the automated tools reports that require manual inspection or confirmation. Future research could probably focus on the different scopes or type of organisations to promote greater awareness on web accessibility among the web developers. Alternatively, other tools also can be applied to compare the results among them or a combination of automated and manual assessments could be another interesting area to explore.

\section{REFERENCES}

Abdul Aziz, M., Wan Mohd Isa, W.A.R., \& Nordin, N., (2010). Assessing the accessibility and usability of Malaysia's higher education websites. Proceeding of the 2010 International Conference on User Science Engineering (i-USEr), pp. 203-208, Shah Alam, Malaysia.

Abdul Latif, M.H., \& Masrek, M.N., (2010). Accessibility evaluation on Malaysian e-government websites. Journal of e-Government Studies and Best Practices. 2010 (2010), 1 - 11.

Abdul Rashid, M. A., Othman, M. N. A., \& Hassan, N. (2014). Discovering Malaysian state e-government maturity stage: Implementation process and progress. Gading Business and Management Journal, 18 (2), 51 - 75.

Abuaddous, H.Y., Jali, M. Z., \& Basir, N., (2013). Study of the accessibility diagnosis on the public higher institution websites in Malaysia. Proceedings of the 4th International Conference on Computing and Informatics (ICOCI 2013), 28-30 August, 2013 Sarawak, Malaysia.

Adepoju, S. A., \& Shehu, S. (2014). Usability evaluation of academic websites using automated tools. Proceeding of 3rd International Conference on User Science and Engineering ( $i$-USEr). 
Andrés, J. D., Lorca P., \& Martínez, A. B. (2010). Factors influencing web accessibility of big listed firms: An international study, Online Information Review, 34 (1), 75 - 97. doi: 10.1108/14684521011024137

Bakhsh, M., \& Mehmood, A. (2012). Web accessibility for the disabled: A case study of government websites in Pakistan, Proceeding of 10th International Conference on Frontiers of Information Technology, 342 - 347. doi: 10.1109/FIT.2012.68

Baowaly, M. K., \& Bhuiyan, M., (2012). Accessibility analysis and evaluation of Bangladesh government websites. Proceedings of the EEE/OSA/ IAPR International Conference on Informatics, Electronics \& Vision (ICIEV 2012).

Boldyref, C. (2002). Determination and evaluation of web accessibility. Proceedings of the Eleventh IEEE International Workshops on Enabling Technologies: Infrastructure for Collaborative Enterprises (WETICE'02).

Chacón-Medina, A.; Chacón-López, H.; López-Justicia, M. D.; FernándezJiménez, C. (2013). The state of web accessibility in Spanish universities according to WCAG 2.0, Revista Española de Documentación Cientifica, 36 (4): 1-13, doi: 10.3989/redc.2013.4.1009.

Comeaux, D., \& Schmetzke, A. (2007), Web accessibility trends in university libraries and library schools. Library Hi Tech, 25 (4), 457 - 477.

Department of Social Welfare. (2014). Report - Statistics of Department of Social Welfare. Retrieved from http://www.jkm.gov.my/file/Buku\%20 JKM\%202014.pdf on 1 June 2016.

Hackett, S., \& Parmanto, B. (2005). A longitudinal evaluation of accessibility: Higher education websites. Internet Research, 15 (3), $281-294$.

Hofstader, C. (2004). Internet accessibility: Beyond disability. Web Technologies. September, 103-105.

Kamoun, K., \& Almourad, M. B. (2014). Accessibility as an integral factor in e-government web site evaluation. Information Technology \& People, 27 (2), 208 - 228. doi: 10.1108/ITP-07-2013-0130 
Laitano, M. I., (2015) Web accessibility in the Argentine public university space. Revista Española de Documentación Cientifica, 38 (1): doi: 10.3989/redc.2015.1.1136

Law of Malaysia. (2008). Person with disabilities act (Act 685). Percetakan Nasional Malaysia Berhad: Kuala Lumpur.

Loiacono, E. T., McCoy, S., \& Chin, W. (2005). Federal web site accessibility for people with disabilities. IT Pro, Jan/Feb, $27-31$.

Lujan-Mora, S., Navarrete, R., \& Penafiel, M. (2014). eGovernment and web accessibility in South America. Proceeding of the First International Conference on eDemocracy \& eGovernment (ICEDEG), 77 - 82. doi: 10.1109/ICEDEG.2014.6819953

Ministry of Higher Education [MOHE]. 2014. National education statistic: Higher education sector. Ministry of Higher Education: Kuala Lumpur.

Noh, K. R., Jeong, E. S., You, Y. B., Moon, S. J., \& Kang, M. B. (2015). A study on the current status and strategies for improvement of web accessibility compliance of public institutions. Journal of Open Innovation: Technology, Market and Complexity, 1 (4), 1 - 17. doi: 10.1186/s40852-015-0001-0

O'Grady, L., \& Harrison, L. (2003). Web accessibility validation and repair: Which tool and why? Library Hi Tech, 21 (4), 463 -470. doi: 10.1108/07378830310509763

Peters, C., \& Bradbad, D. A. (2010). Web accessibility: An introduction and ethical implications, Journal of Information, Communication and Ethics in Society, 8 (2), $206-232$.

Pribeanu,C., Marinescu, R.D., Fogarassy-Neszly, P., \& Moisii, M. G. (2012). Web accessibility in Romania: The conformance of municipal web sites to web content accessibility guidelines. Informatica Economică, 16 (1), 28-36.

Providenti,ZaiIII, R.(2007).WebaccessibilityatKentucky's academiclibraries, Library Hi Tech, 25 (4), 478 - 493. doi: 10.1108/07378830710840446 
Ramayah, B., Jaafar, A., \& Mohd Yatim, N.F. (2010). A study on web experience among visually impaired users in Malaysia. Proceedings of the 2010 International Conference on User Science Engineering (i-USEr), 11-15, Shah Alam, Malaysia.

Ribera, M., Porras, M., Boldu, M., Termens, M., Sule, A., \& Paris, P. (2009). Web content accessibility guidelines 2.0. Program: Electronic Library and Information Systems, 43 (4), 392 - 406. doi: 10.1108/00330330910998048

Roggio, A. (2016). Common Web Accessibility Problems on Leading Ecommerce Sites. Retrieved March 9, 2016, from http://www. practicalecommerce.com/articles/96547-Common-Web-AccessibilityProblems-on-Leading-Ecommerce-Sites

Rømen, D., \& Svanæs, D. (2012). Validating WCAG 1.0 and WCAG 2.0 through usability testing with disabled users. Universal Access in the Information Society, 11 (4), 375-385. doi: 10.1007/s10209-011-0259-3

Schimmel, K., Motley, D., Racic, S., Marco, G., \& Eschenfelder, M. (2010). The importance of university web pages in selecting a higher education institution. Research in Higher Education Journal, 6 (September), 1 - 16.

Serra, Carvalho, Ferreira, Vaz and Friere. (2015). Accessibility evaluation of e-government mobile applications in Brazil. Procedia Computer Science, 67, 348 - 357. doi: 10.1016/j.procs.2015.09.279

Shawar, B. A. (2015). Evaluating web accessibility of educational websites. International Journal of Emerging Technologies in Learning, 10 (4), 4-10. doi: http://dx.doi.org/10.3991/ijet.v10i4.4518

Shawn, L. H. (2006). Web accessibility: Web standards and regulatory compliance. Friends of Ed.

Shi, Y. (2006). E-government web site accessibility in Australia and China: A longitudinal study. Social Science Computer Review, 24 (3), 378-385, doi: $10.1177 / 0894439305283707$

Smith, J. (2007). Alt text and linked images. Retrieved March 9, 2016, from http://webaim.org/blog/alt-text-and-linked-images/ 
WebAIM. (2013). Accessibility evaluation tools, Retrieved October 3, 2015, from http://webaim.org/articles/tools/

Williams, R., \& Rattray, R. (2003). An assessment of web accessibility of UK accountancy firms, Managerial Auditing Journal, 18 (9), 710 - 716, doi: $10.1108 / 02686900310500460$

Williams, R., \& Rattray, R. (2005). UK and US hotel web content accessibility, International Journal of Contemporary Hospitality Management, 17 (1), 78 - 87. doi: 10.1108/09596110510577699

World Wide Web Consortium (W3C). (1999). Web content accessibility guidelines 1.0. Retrieved September 9, 2015, from http://www.w3.org/ TR/WCAG10/

World Wide Web Consortium (W3C). (2005). Introduction to web accessibility. Retrieved September 9, 2015, from https://www.w3.org/WAI/intro/ accessibility.php

World Wide Web Consortium (W3C). (2008). Web content accessibility guidelines (WCAG) 2.0 Retrieved September 9, 2015, from http:// www.w3.org/TR/WCAG20

World Wide Web Consortium (W3C). (2009). Retrieved September 9, 2015, from http://www.w3.org/TR/egov-improving/

Yates, R. (2005). Web site accessibility and usability: Towards more functional sites for all, Campus Wide Information Systems, 22 (4), 180 - 188. doi: 10.1108/10650740510617494 